\title{
B3GAT1 Gene
}

National Cancer Institute

\section{Source}

National Cancer Institute. B3GAT1 Gene. NCI Thesaurus. Code C101762.

This gene plays a role in glycoprotein modification. 